\title{
䠌贸周望
}

\section{水環境工学における成分の流れと収支の評価 \\ EVALUATION OF WATER QUALITY AND ITS \\ FLOW IN WATER ENVIRONMENT}

丹保憲仁*

By Norihito TAMBO

\section{1. 物質収支と境界}

大きな環境系であれ，処理プロセスであれ，いかなる 境界を考えた場合でも，これらの境界内に入ってくる物 質量は, その系から出ていく物質量と境界内部に生成も しくは蓄積した量を加えたものに等しくなければならな い.これは「質量保存の法則」の 1 つの表現であり, 個々 の物質についてはもちろんのこと, 総物質量についても 厳密に適用されねばならない。

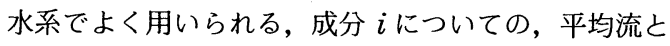
拡散による輸送, 重力などによる各方向への輸送, 系内 への蓄積および反応による増減を考えた収支式の一例を 示すと式（1）のようである.

$$
\frac{\partial c_{i}}{\partial t}+\left(u_{x} \frac{\partial c_{i}}{\partial x}+u_{y} \frac{\partial c_{i}}{\partial y}+u_{z} \frac{\partial c_{i}}{\partial z}\right)
$$

系内への蓄積境界を通しての平均流による輸送

$$
\begin{aligned}
& +D\left(\frac{\partial^{2} c_{i}}{\partial x^{2}}+\frac{\partial^{2} c_{i}}{\partial y^{2}}+\frac{\partial^{2} c_{i}}{\partial z^{2}}\right)+q_{i}
\end{aligned}
$$

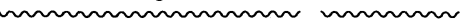

$$
\begin{aligned}
& \text { 境界を通じての分散による輸送境界を通じての } \\
& +\underset{i}{r_{i}}=0 \\
& \text { 系内で変化 }
\end{aligned}
$$

ここで, $c_{i}$ : 成分 $i$ の濃度, $t:$ 時間, $x, y, z$ : 直角 座標上の距離, $u_{x}, u_{y}, u_{z}: x, y, z$ 方向の流速, $q_{i}$ : 外力によって境界外へ移動する速度, $r_{i}$ ：反応速度, $D$ : 分散係数

一般には，系の物質収支を 1 本の式（1）で表現する

* 正会員 工博 北海道大学教授 工学部衛生工学科 （厂060 札幌市北区北 12 条西 8 丁目）
ことはできない，なぜならば，系内での成分の変化速度 を示す左辺第 5 項を通じて, $i$ 成分以外の $j, k, \cdots, n$ といった成分間の交互作用を考えねばならぬためであ る.したがって，与えられた環境空間における物質収支 の式は，考えねばならぬ成分数 $n$ についての $n$ 個の連 立方程式 $(i=1 \sim n)$ ということになる.

環境における物質収支を記述するこのような連立方程 式を解くためには, 変数の数に応じた, 初期条件と境界 条件を与えねばならない。

境界の限定の仕方に応じて, 対応しなければならない 成分数は, 1 から無限に近い多数まで変化する. そして, そのどこかに，制御のために費やされる努力之評価のた めの費えの両者を考えた場合の適切なシステムの複雑さ

（規模）があるはずである.したがって，現実には，境 界条件をどのように与えるかが，活動空間（実際に現象 が生じている空間）とそれを支える環境空間を物質収支 を明らかにしつつ適切につなぐ, 境界制御構造の設計問 題という, 環境・衛生工学の主題となって現われてくる.

\section{2. 動力学 項}

環境・衛生工学が対象とする, 水・空気といった物質 代謝を支える流体系の保全に際しては，含まれる諸成分 を水・空気・土壌の 3 系へどのように分配するかを論ず ることになる。したがって, 対象とする $n$ 成分の輸送 之相互の変換を 3 相系の中で可能な限り収支を正確に とっていくための手法が必要になる.

このような場合, 先にも述べたように, 環境での収支 を論ずる式（1）は, 動力学項を介して連立している.

一番簡単な場合を例に挙げる. $A, B 2$ つの成分があっ て相互に作用しあって成分 $R$ が生成する. 
$A+B \rightarrow R$

この場合反応速度項の最も簡単な形は式（3）のようで あろう。

$\left(-r_{A}\right)=k C_{A} C_{B}$

式 (3) を介して, $A, B, R$ という 3 成分に対する物 質収支の式を 2 本連立に解くことになる.

動力学項は一般に非線形であって, 複雑な多成分を含 む反応 (生物化学反応など) を介しての環境中の物質収 支の勘定は, 非線形の多元の連立偏微分方程式を解かね ばならぬこととなり, 最新の数值計算法と計算機によっ てもきわめて難しいこととなる.

工学者が反応速度を理論的に表現することはきわめて 困難であり, 多くの場合設計やシミュレーションが可能 な程度の数の実測し得る成分 (指標) についてそれらし き近似モデルを用いて反応の進行を表現するのが精一杯 である．最も極端な場合には，変換した成分が無害化す るとして, 対象となる有害成分のみの変化に現象を限つ て，物質収支をとることを放棄したうえで収支式を減衰 式として運用する場合も少なくない文(例：StreeterPhelps の水質方程式).

また多くの場合, 対象とする成分数を小数に限っても, 式（1）に示したような複雑な輸送項をもつ収支式（移 流・拡散モデル）で現象を記述することができず，より 簡単な輸送項を用いて収支を表現せざるを得ない。この ような場合には, 分散項を除き, 移流項も現象の進行の 最大傾斜方向についての唯一の微係数によって表現する 式(4)のような押出し流れモデル (plug flow model)や, 完全混合槽の直列配列によって空間を分割し，分割され たサブ空間内には現象の勾配が一切ない巨視的表現法で ある式 ( 5 ) のような槽列モデル (tank in series model) などを用いることとなる ${ }^{2,3)}$.

$$
\begin{aligned}
& \frac{\partial c_{i}}{\partial t}+u_{x} \frac{\partial c_{i}}{\partial x}+q_{i}+r_{i}=0 \\
& \frac{\partial c_{i}(j)}{\partial t}+Q(N / V)\left(c_{i}(j)-c_{i}(j-1)+q_{i}+r_{i}=0\right.
\end{aligned}
$$$$
j=1 \sim N \cdots
$$

ここで, $V:$ 現象を考える空間の大きさ, $N$ : 空間の直 列等分割数, $c_{i}(j)$ : 第 $j$ 番目の槽の成分 $i$ の濃度

したがって, 現実には, 輸送項と動力学項の詳しさを, 対象とする現象に対してどのようにバランスよく用いる かが環境における収支を適切に記述するための鍵亡な る. 物理系の人々が輸送項を精密に扱うことに力点を置 きがちであったり, また化学系・生物化学系の人々が反 応を詳述しようとするあまり, 輸送項との重㸚合わせに 頓着せずにひたすら反応の分析に進むといったことも 間々みられる. 環境・衛生工学の主題は質であり, それ をいかに空間に適切に配分するかであることを考える
と，輸送と動力学項を境界条件と成分数に応じてどのよ うな形式で精度を均衡させて扱うかといった研究が緊要 のように思われる.

時としては境界を通じての移動を示す項 $q_{i}$ も反応速 度の形式によって表現される場合が少なくない.このよ うな場合に，反応項と外力による輸送項を合体して質の 変化を反応項で表現しようとすることになる．このよう な場合には形式は反応項であっても物質の変化と輸送を 同一項で扱っているので，物質の収支を正当によること ができない，減衰または生成式としての扱いとなる.

このように環境・衛生工学での物質の輸送と変化を表 現する場合には，成分を保存量として扱うか否かによっ て記述の複雑さが全く違ってしまう。無用に問題を複雑 にする必要もないかわりに, 必要な式の連立（複数の成 分相互の関係) を省略しすぎぬことが重要である. 例を 挙げて考えてみよう.

\section{BOD と Streeter-Phelps-Eckenfelder 体} 系

『水質污濁に係る環境基準（昭 46.12，環境庁）』の河 川の環境保全にかかわる主要指標として, 溶存酸素量 (DO) と生物化学的酸素要求量 (BOD) がある.

河水を取水し, 利用し, また河川へ戻すといった一過 型の水利用を通常としている都市・地域の水代謝系で問 題が生ずるとすれば，それはまず廃水が陸水か沿岸水に 排出されたときに，排出地先近傍に局所的に生ずる高濃 度成分に由来する害であろう ${ }^{4}$.

その代表的な現象が，空気中には $20 \%$ 強もありなが ら水中にはわずか $10 \mathrm{ppm}(0.0001 \%)$ しか溶けること ができぬのに, 水中に普遍的な好気性生物の生存のもと 亡なっている溶存酸素 (DO) の不足である. しかもそ の不足を生ぜしめる主成分が生活系廃水中の最大量を占 める生物分解性有機物（後述する BOD 成分）であるこ とから, 水が大循環経路に沿って移動し海洋で完全に水 質が再生される以前に淡水が被むる污染の最も代表的な 現象として, 流域の局所における酸素不足 (oxygen deficit，OD）がまず最初に問題となった.

水中に溶存酸素不足が生ずると, 好気性 (aerobic) の生態系に悪影響が生じ，極限では嫌気性 (anaerobic) となって, 好気性の一般水棲生物群が壊滅してしまうこ とから, 酸素不足 $(O D)$ 概念に基づいて水質の劣化を 評価しようということが始まる。そこで, 酸素要求を誘 起する水中の諸成分による酸素消費量 (oxygen demand) と空中からの酸素補給 (reaeration) の間の平衡 を考えて水中の溶存酸素濃度レベルをある值以上に保と うとすることが, 従来型の水代謝系の污染制御の主たる 考え方となる. 


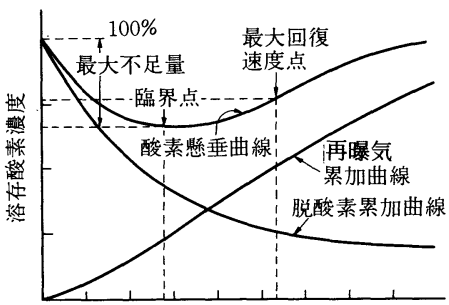

流下時間（距離）

図一1 河川における溶存酸素収支

Streeter とPhelps によって確立された式（6)，図一 1 に示されるような酸素不足曲線 (oxygen sag curve) がこの現象の基礎的な表現である ${ }^{1)}$.

$$
\frac{d D}{d t}=K_{1} L-K_{2} D
$$

ここで, $D:$ 飽和值からの酸素不足量, $L:$ 水中の $\mathrm{BOD}$ (生物化学的酸素要求量), $K_{\mathbf{1}}$ : 脱酸素速度係数,

\section{$K_{2}:$ 再曝気係数}

この式で最も重要なことは, 酸素不足の程度によって 示される水環境レベルを支配する污濁成分示標としての BOD 概念の導入である.

有機物 $+\mathrm{O}_{2} \rightarrow \mathrm{CO}_{2}+\mathrm{H}_{2} \mathrm{O}+($ 第三成分群 $)$

有機物の酸化速度が最も簡単な濃度の一次反応で示され るとし, 式 $(7)$ の左辺のように反応に関与した有機物 と $\mathrm{O}_{2}$ の量比が一定であるとすると, 式 (8) の関係が 成立する.

$$
\frac{d(\text { 有機物 })}{d t}=\text { (定数) } \frac{d(\text { 必要酸素量 })}{d t}
$$

したがって, 水中で微生物によって酸化される有機物量 を対応する酸素量で表現し, 流水中の酸素の収支と結ぼ うと考え, しかも多種多様な生物分解性の有機物量を酸 素という簡単な無機物量で置き換えるという巧みな単純 化・示標化をやってのけ, BOD 試験という簡単な検出 法によって定量化を果たす.

ここで重要なことは, 酸素もその陰にみえかくれする BOD 成分なる呼称で一般にグルーピングされている有 機物もその扱いで保存量としての収支を考えていないこ とである，複雑な成分を単純化して表示し，反応速度を その濃度の一次とし, 収支を考えず, 局所の酸素不足量 のみに着目して水質レベルを評価しようとする簡略化 は，精度は十分でないにしても端的な現象の表現法とし て大きな有用性を発揮してきた.

生物化学的酸化反応も詳細にみれば, 生物分解性有機 物濃度（実際にはBOD で表現される酸素当量）の一次 反応で表現するのは無理として，モノの式，ミカエリス メンテンの式などが用いられたり ${ }^{51}$, 一次反応を仮定し 得る場合でも, 定数が反応の進行による基質の平均組成
の変化や生物群集濃度の増減によって変化するといった 扱いをしなければならなかったり ${ }^{6)}$, 簡単でない場合が 少なくない. 多くは, 総括的な均一一次反応の型で問題 を扱っているが, 水中の BOD 成分は懸濁, 溶解両成分 にまたがって分布している.したがって, 沈殿や物理吸 着といった化学反応外の固液間の輸送にかかわる変化も 考えなければならないような場合, マクロ均一系として 扱える範囲で現象が進む液系から懸濁系 (微生物) への 吸着のような場合と, 水系から底質土堙系への沈殿分離 のような系を異にする空間への移動の両者がある．河川 での式（6）の運用にあっては, 基質の分解, 吸着, 沈 殿等を込みにして，それぞれの変化がそれぞれの濃度の 一次反応で進行し，その線形の結合として結果を表現し 得るとして, 全 BOD 成分についての一次反応として, 総括脱酸素係数 $K_{r}$ を導入する ${ }^{7)}$. 先に収支式のところ で述べた，輸送現象をも反応項で表現する例である.

酸素不足量の議論を行うに際して, Streeter-Phelps の原式である式（6）は, 生物化学反応による水中酸素 の減少と気系からの酸素の補強だけを論じている. しか しながら，上述のように $K_{r}$ なる総括脱酸素係数を考え るということは, 少なくとも未分解成分が底質上面に堆 積することを含んでの表現であるから, 流れ方向の一次 元の移流による輸送といった最も簡単な輸送系しか考え ない通常の Streeter-Phelps 式 (式 (6) の $\frac{d D}{d t}=u$ $\frac{d D}{d x}$ と変換する）の場合, 反応項の型で底質から水への 酸素要求量 $(\mathrm{BOD})$ を付加しなければならなくなる. この場合底質から水中に負荷される BOD は本来的には 総括脱酸素係数 $K_{r}$ にくくられてその一部となった沈殿 した BOD 成分の再来部分である．沈殿の項を反応項の 一部に丸めたことによって，底質での酸素要求量の生成 を記述する項がなくなっており，本来は沈殿によるもの と底質から再溶出するものの両者を水系と土壌系で収支 させるべきところを，ただ単に土㙋系（底質）から水系 への負荷として独立に表現することになる．

したがって，水と土系の相互作用を考えるならば，保 存量と考えられない成分でも，外力による輸送項と反応 項の分離は, 式の成立に基本的な事項であり，単なる修 正式としての扱いのみで斉まない場合が少なくない. Total BOD のみを計測して行い得る河川の環境管理の 限界である。

Streeter-Phelps の基本的な概念は流水の局所的な溶 存酸素不足が水環境劣化の最も顕著な場合であるという ことによっている.しかしながら，わが国のように河川 が急流で再曝気係数 $K_{2}$ が非常に大きな水環境では, 酸 素不足量が直接問題になることは，感潮部を除いてほと んよ゙ない.また，わが国では大きな感潮河口部をもつ河 は必ずしも多くない，そのために，わが国ではBOD 值 
を生物分解性有機物濃度そのものの総括示標として扱 い, 酸素収支の概念外で論議が進んでいくこととなる. 環境基準の類型 $\mathrm{AA}, \mathrm{A}, \mathrm{B}$ などの $\mathrm{BOD}$ レベルが, 1,2 , $3 \mathrm{ppm}$ といった数值はこのことを如実に物語っている.

したがってわが国の河川環境の一般的な評価式は, 原 理的な式（6）ではなく, 式（8）の左辺そのものを扱 う式（9）の表現となる.

$$
\frac{d L}{d t}=-K_{1}^{\prime} L
$$

\section{ここで, $K_{1}^{\prime}: \mathrm{BOD}$ 減少係数}

このような式は単なる生物分解性の有機物が液系濃度の 一次反応で減少することを示す最も単純な動力学表現で ありこれを Streeter-Phelps の式とするのは誤りであ ろう. 酸素不足の概念 (oxygen deficit) とかかわりの ない有機成分の減衰を示すのであれば，何も酸素当量と して有機物量を示す必要もないことになる.

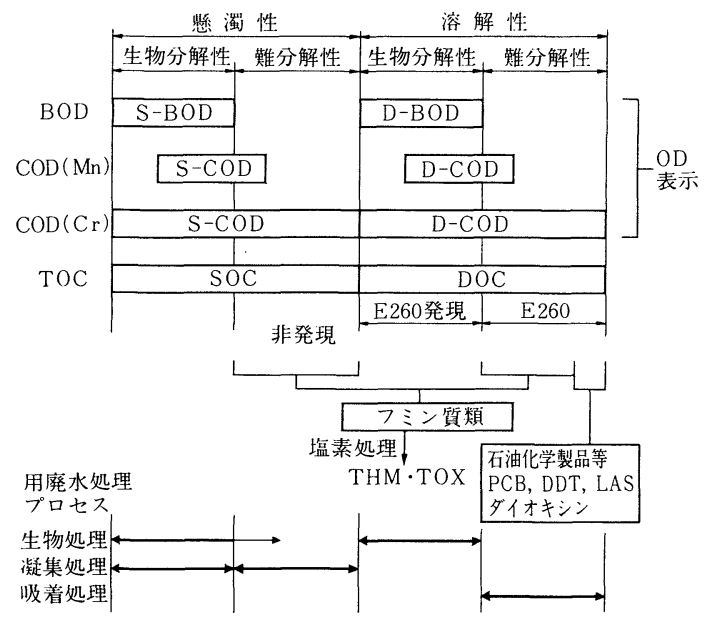

図一2 有機指標のさまざま

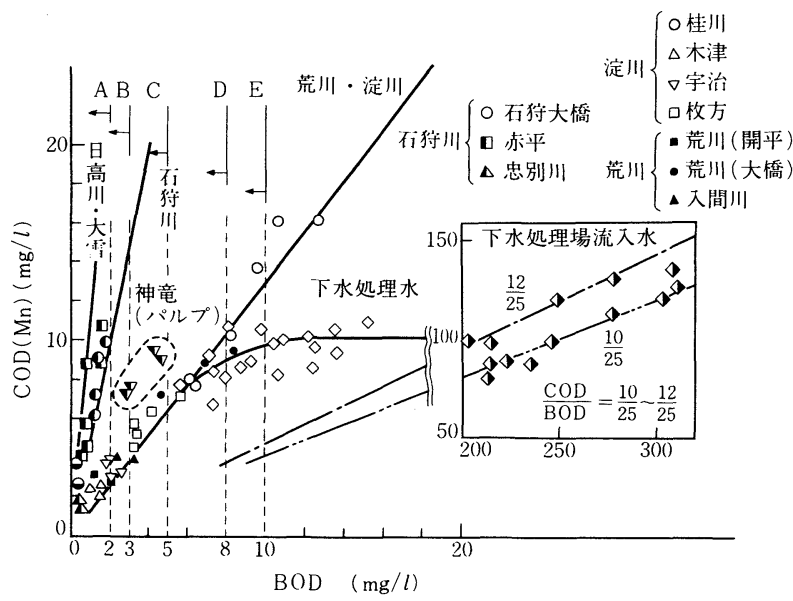

図一3 河川・処理系の BOD と COD
有機物量そのものを示すのであれば, 全有機炭素量 (total organic carbon, TOC) が最も端的な示標であ ろう ${ }^{8)}$. 現用されている酸素消費概念に基づく有機水質 示標群で TOC に対応するのが, 化学的酸素消費量 (chemical oxygen demand) で式（8）の関係から示 される全酸素要求量 (total oxygen demand, TOD) に 近いものとして重クロム酸 COD が世界各国で用いられ ている ${ }^{8)}$. かが国では旧来の過マンガン酸カリウム COD を用いて環境基準の湖沼・海洋等における有機物 量を酸素消費量として示そうとしている ${ }^{9)}$ が, 図一2に 模式的に描くように総有機物量を表現し得ず, 重クロム 酸 COD と異なって収支を論ずる基礎指標となりにく く,わが国の水環境評価指標の最大の弱点となっている. 国際間ではほとんど評価されぬ過マンガン酸カリウム COD を用い続けることは大きな問題である.

図一3 はわが国の代表的ないくつかの河川の各地点の 水亡典型的な活性污泥法による好気性微生物処理前後の 下水の BOD と過マンガンカリウム COD の值を水質年 報, 処理場日報の長年月の同時期の測定値を平均した值 についてプロットしたものである. 下水処理放流水が主 成分となっているか, または水中の有機成分が生活廃水 等が生物分解を経たもの（いわゆる自浄作用等による） と考えられる淀川・荒川などでは BOD/COD $(\mathrm{Mn})$ は 1/1. 2 1. 3 程度であり, 類型基準 $\mathrm{A}, \mathrm{B}$ のような清澄 な河川では，1：5以上にもなる.一般的な理解によれば COD－BOD の值は生物難分解性の有機物量を示すとさ れて, この場合もある割合の值が生ずる.しかしながら, 振り返って下水そのものの BOD/COD $(\mathrm{Mn})$ 比をみる と, $2 \sim 2.5$ となって, BOD 成分がはるかに多く, $\operatorname{COD}(\mathrm{Mn})$ はとうてい有機物総量の示標たり得ないこ とを示す．このように，水環境評価の主指標とされてい

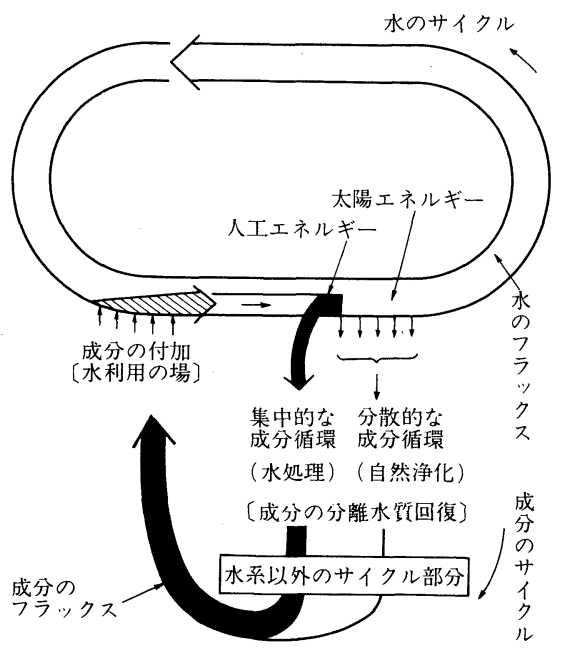

図一4 水サイクルと共役な成分サイクル 
るものさえ，収支を論ずる基礎となり得ないことは由々 しいことである. 流域計画の 1 人 1 日原単位として用い られている BOD $50 \mathrm{~g} /$ 人/日， $\operatorname{COD}(\mathrm{Mn}) 27 \mathrm{~g} /$ 人/日も 同様のことを示している.

水質污濁という現象は，図一4に示すように，水サイ クル上の自然水域がある用途に対して指定され，その許 容水質レベルが定められた場合に，水サイクルと共役な 成分サイクルが定められた濃度範囲内で定常に達するこ とができず,より高濃度化(または低濃度化)していくか, または高濃度（低濃度）で平衡してしまうことをいう. したがって，污濁とは空間の用途（保持すべき水質レベ ル）を指定して初めて定義される現象である.

自然水域を介しての成分フラックスが過大で平衡レベ ルが考えている值を越えてしまい, 水質污濁が生じたと 認識される場合には，水サイクル上の適当な位置に過剰 な成分フラックスを集中的にバイパスさせる空間を設け る.これが水処理である. 広い自然水域に分布して，太 陽エネルギーによって維持されていた成分循環フラック スを，狭い人為空間に集中して大きなフラックスとして 処理しようとするのであるから, 循環の加速のために多 量の人工的エネルギーが必要になる.

現在の水環境評価のための主指標が懸濁成分 (SS) と BOD 成分であることから, 制御の対象となり, 水サ イクルから集中的に分離される成分も SS と BOD 成分 ということになる. 現用の下水処理が対象とする成分で ある. 原廃水中の SS 成分の分離, 特に無機的な成分の 分離は比較的明快なことから，ここでは BOD 成分につ いて論ずる.

Streeter-Phelps によって定型化された酸素不足によ る污濁の防止は, 当然のことながら酸素不足を来す $\mathrm{BOD}$ 成分の除去によって成し遂げられ，OD 概念を基 本とする水環境制御の中心施策となる.この問題の定式 化は Eckenfelderによって集大成されたと考えてよいで あろう ${ }^{10)}$. 金子の要約に従うと ${ }^{11)}$ ，好気性条件下で(1)有 機物の酸化分解, (2)菌体の合成, (3)自己酸化の 3 つの反 応がそれぞれ式 (10)，(11)，(12）のように示される.

有機物 (BOD 発現) の減少速度

$$
-\left(\frac{d L}{d t}\right)_{u}=-\left(\frac{d L}{d t}\right)_{u G}+b_{1} S
$$

污泥増加速度

$$
\left(\frac{d S}{d t}\right)_{a G}=Y\left(\frac{d L}{d t}\right)_{u}-b_{2} S
$$

酸素吸収速度

$$
r_{r}=\left(\frac{d O}{d t}\right)_{A}=a_{0}\left(\frac{d L}{d t}\right)_{u G}+b_{3} S
$$

ここで, $L$ : 廃水の BOD 濃度, $S:$ 処理系の活性微生 物（污泥）濃度, $Y$ : 活性微生物群（污泥）に移行した
BOD 成分の固系への転換率, $b_{1}$ : 活性微生物群の自己 分解による BOD 再溶解率, $b_{2}$ : 活性微生物群の自己分 解による減少率, $b_{3}$ : 活性微生物群の自己分解の際の酸 素吸収率, $(d L / d t)_{u}:$ 微生物反応における有機物の総 減少速度, $(d L / d t)_{u G}$ : 活性微生物群の有機物利用速度, $(d S / d t)_{G}$ : 活性微生物群の真の増殖速度, $(d O / d t)_{A}$ : 活性微生物群による酸素吸収速度

$Y, b_{1}, b_{2}, b_{3}$ 等の值が知られていて, 微生物群の増 殖速度の定式化（一般には微生物濃度の一次反応を考え る）が行われれば式（10）と（11）を連立させて，固体 化する成分量を求め, BOD 減少量, したがって酸素要 求量をどこまで低下させ得たかを知ることができる.

BOD 成分量が保存量でないにしても，境界が処理装 置で画然としているので, 反応によって固体化する成分 （固夜分離される成分）亡液系に残る成分を算出し，自 然水系と土壤系の負荷分配を明確にし，必要な酸素量を も算出できる．このように全水系に比してきわめて限ら れた空間で, 水系の酸素要求量を減じ, 土系への負荷を 算定し, 大部分の成分をしかるべき空間 $\left(\mathrm{CO}_{2}\right.$ となっ て気系へ，污泥となって土系へ，わずかな成分が水系へ 残る) へ分配される.したがって，処理系の整備が進ん だ際に残された水系の成分は，もはや酸素消費の成分亡 してではなく, 酸素消費が問題えなうた成分として, $\mathrm{BOD}$ 值による水域の環境基準で処理系とのコンシステ ンシーを保って表示され続けることとなる.したがって， $\mathrm{BOD}$ 值が水質保全上の価値亡直接連接される必然性は もはやないこととなる.

このような型で現存している水環境制御の体系を, Streeter-Phelps-Eckenfelder の体系と名付けることが できよう.

\section{4. 高度水管理系で問題となる諸成分}

日本のような高密度社会にあっては, 流域にある水利 用(排除)が単独に存在しているのは例外的な場合であっ て, 都市・農業・工業等の水利用が繰返し行われている のが常態となってくる. 長大河川の上下流に諸活動が 延々と連なる欧米の大陸諸国家では, 繰返しの度合いは 日本に比して極端であり, 利水を可能にする条件はすで に水量的なものから水質に規定される状況となってい $ろ^{4), 12)}$.

このような状況下では, 制御の対象となる成分は, Streeter-Phelps-Eckenfelder 系のような BOD, SS 成 分のみではあり得ない. 繰返し利用を行うのであるから, 上述の BOD, SS といった成分の高濃度の存在はもち ろん許されない. 加えて, 一過型の水利用ではあまり問 題とならなかったけれども繰返し利用で蓄積されて問題 となる成分群として, 生物難分解性の有機物 (refractory 
organics）や窒素・リンなどの無機栄養塩などを考えな ければならなくなる。もちろん生態系で濃縮されて生理 的な毒性を生ずる，人の健康保護に関する環境基準に挙 げられているカドミウム，有機りンなどの成分は一過型 水利用，繰返し水利用を問わず問題となるが，後者にお いてその危険の度合いは大きく増大する.

そこで，これら諸成分をどのように扱って，水環境系 における成分の流れと総合的な収支を考えるとよいかを 検討してみる必要がある.

\section{（1）繰返し水利用系で問題となる有機物}

問題となる有機物を大別して考えると，(1)従来より水 系の有機物の主指標と考えられていた BOD 成分や， SS 成分が繰返しにより累加して, 下流水質が重疊的に 悪化してくる問題と，(2従来ほとんど問題とされてこな かった生物代謝廃成分であるフミン質などの難生物分解 性有機成分の蓄積や, (3)農薬などの微量の石油化学製品 の存在である.

(BOD 成分の問題)

わが国の下水処理場の放流水の基準は，最も多く用い られている活性污泥法等による処理水で BOD $20 \mathrm{ppm}$, SS $70 \mathrm{ppm}$ 以下とされている. 都市が繰返し水利用を 行おうとすると, 現行の水質類型分類でいうならば $\mathrm{B}$ 類 型以上を保持しなければならないが，河川と上水道を通 過する流量比が $1 ： 1$ 以下になりつつある現在の都市化 した河川では，BOD $20 \mathrm{ppm}$ といった放流基準では繰返 し利用は困難である。

しかしながら，一般に用いられている活性污泥法によ る下水処理場では, 都市廃水中の生物分解性の有機成分 のほとんどは活性污泥により吸着・分解されていて，放 流前に凝集・濾過を加えると BOD 值で $3 \mathrm{mg} / \mathrm{l}$ 以下に することができる.したがって，固液分離を現用の沈殿 のみに止めずに，濾過または必要に応じて凝集・滤過を 考えることによって類型 B を下水放流水のみで達するこ とも可能となる.

低濃度の BOD を発現する成分として, 生物分解性の 有機物のみならず，アンモニアの硝化反応による BOD

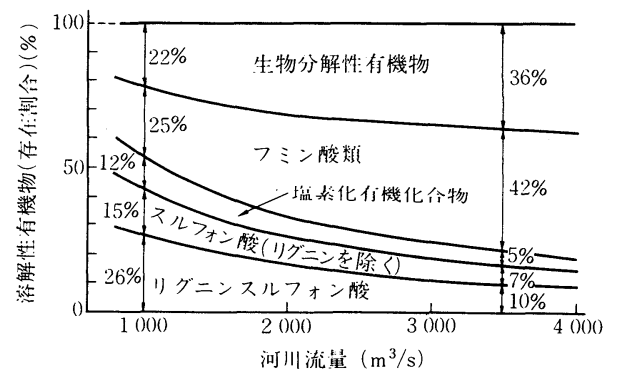

図一5 ライン河下流における河川流量と主要な溶解性有機成分 の存在比
も加わってくるので，その内容に対する詳細な検討を後 述する全有機炭素を中心指標として，成分間の関連をと りつつ行う必要がある.

(生物難分解性の代謝廃成分)

生活用水等の利用を流域で繰返していくと，現在の水 代謝の型態での繰返しでは, 生物難分解性の有機成分が 徐々に蓄積してくる. 図一5 は世界的にみても繰返し利 水回数の大きいライン河の独・蘭国境付近での有機成分 の存在状態を流量との対比によって示したものであ $3^{14)}$. 図中の生物分解性有機物 (BOD 成分) は, 低水 時で $22 \%$ ，高水時でも $36 \%$ にすぎない，これは低水 時に流下時間（滞留時間）が長くなり流入までと河道で の分解が進むためと考えてよいであろう。

生物難分解性の有機物が水中の有機物の大きな割合を 示している場合には，先にも述べたように，現用の過マ ンガン酸カリウム COD のもつ定量性の不十分さは受け 入れ難く, 重クロム酸 COD の導入が必須となる。 また, 全酸素消費量（TOD）といった触媒を用いて高温で有 機物を酸化させ消費された酸素量を求めようとする試み もある．しかしながら，自然系で酸化することのない生 物難分解性有機物すべてを酸素当量で表現することはほ とんど無意味であり，有機物質の当然の示標である全有 機炭素量（TOC）で表現する方がより自然である．図 -2では TOC を懸濁性有機炭素 (SOC) と溶解性有機 炭素 (DOC) で示してある.これらについて生物分解 性の有無やその他の挙動を論ずる方がより正確な水代謝 系の挙動評価につながる. 式（1）の左辺第 4 , 第 5 項 である外力による輸送（分離）亡動力学項（変化）を論 ずるには最少限度懸濁質と溶質の分離評価が不可欠であ ることは先述のとおりである.

丹保・亀井らは, 先に BOD, COD に代わり得る, 物質収支を満足しかつさまざまな水質変換プロセスにお ける水質変化の情報をもつグループに有機物群を分類す るゲルクロマトグラフィーに基づく水質マトリックスを 提案して, $\mathrm{mg} / l$ オーダーまでの一般有機物の水環境に おける挙動の総合的指標化を可能にした ${ }^{15), 16)}$. 環境中や 処理水中に存在している多種多様の微量成分を個々に同 定・定量し，なおかつ全体の収支を常に把握し続けると いったことを現在の有機化学や分析化学の力量と技術で 行い続けることは不可能である. そこで, 丹保・亀井ら は溶解性有機物の全体を，その成分の寸法（見掛け分子 量）と TOC/E 260 比（ここで，E 260 は紫外線部 260 $\mathrm{nm}$ の $1 \mathrm{~cm}$ セルにおける吸光度）の 2 つのみを指標之 して溶解性有機物を少数のグループに分類し，環境や処 理系中の挙動と関連づけ，水質制御のための総合的な評 価手法とし得ることを多くの実験的検討の結果に基づい て報告している ${ }^{16)}$. 


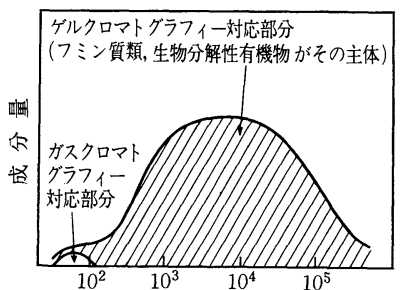

分子量 $(\mathrm{MW})$

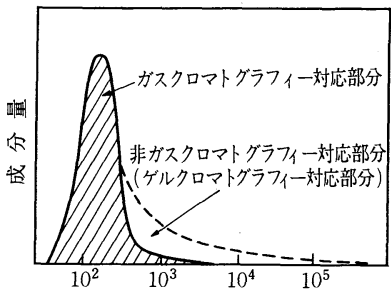

分子量 $(\mathrm{MW})$

図一6 ゲルクロマトグラフィーとガスクロマトグラフィーの対 応領域

図一6は水環境における有機成分の評価に用いられる 2 つの代表的な分離法であるゲルクロマトグラフィーと ガスクロマトグラフィーの分離の特徴を示したものであ る.

ゲルクロマトグラフィーは微量の低沸点有機物や極端 に疎水性の大きな有機物を除いて，量的にほとんどすべ ての水中の有機物を見掛け分子量の大小に応じて分類で きる. しかも，このようなゲルクロマトグラフィーで分 離できる不揮発性の水中有機物はその挙動から疑似 2 成 分系として扱うことができる17),18).

その第 1 の成分群は, 炭水化物, 脂肪族有機酸などに 代表される生物易分解性の有機物群であり, 紫外部 260 $\mathrm{nm}$ の吸光度 (E260) を示さない有機炭素量 (TOC) として定量化される.この成分はBOD 成分にほぼ対応 している.

第 2 の成分群は生物難分解性の有機物群であって, フ ミン質類がその量的主体をなす。フミン質類は，一般に よく知られているように, 泥炭地や沼沢地の着色水中の 有機物の主成分であるのみならず，林地からの清澄な水 や湖沼水中でも有機物の主体をなす（絶対量は少な ( $)^{18)}$.これら成分はまた, 第 1 主成分である生物易分 解性有機物が好気性微生物によって分解される際に水系 に再廃出される微生物代謝廃成分であり, 原廃水の炭素 濃度の 3 5\% の炭素濃度で廃出される ${ }^{19)}$. したがって 好気性下水処理では，TOC の除去率は 95～97\% がせ

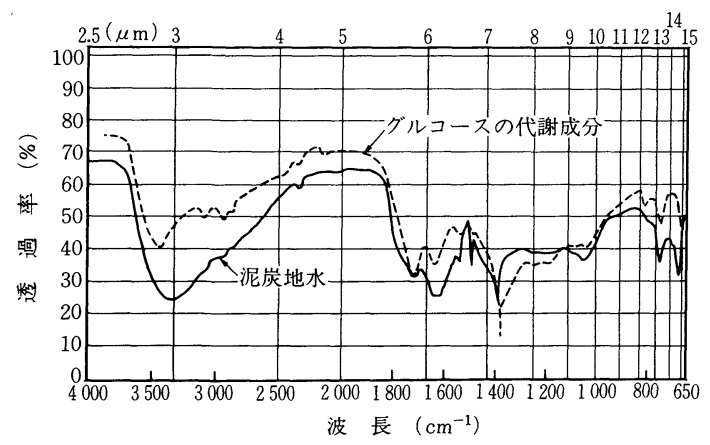

図一7色と生物代謝成分の赤外吸収スペクトル

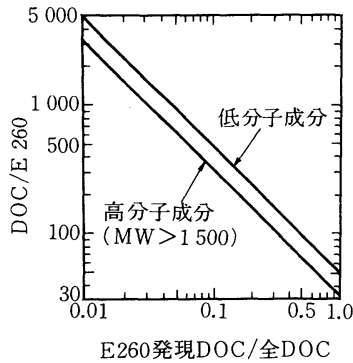

図一8 生物難分解性有機物の存在比と DOC/E 260

いぜいである。このようにして生成した代謝廃成分は図 一7の赤外線スペクトルにみられるように泥炭水中の着 色成分と同様のフミン質類である ${ }^{20)}$.このような成分は 紫外部 $260 \mathrm{~nm}$ に吸光度をよく示し, TOC とE260 の比 が，30〜50 の成分として性格付けることができる ${ }^{16)}$.

上述のように，有機物の量的な主体は，E 260 発現性 の生物難分解性成分（フミン質類）とE260 非発現性の 生物易分解性成分の 2 成分群に大別でき，フミン質類の TOC/E 260 比が 30 (高分子のフミン質) 50（低分子 のフルボ質）で示され, 生物分解性成分群が E 260 の值 を示さないことから，䯚濁成分を濾別した溶解性有機炭 素 (DOC) と紫外部 $260 \mathrm{~nm}$ の吸光度を測定して, DOC/E 260 比を知れば，図一8からただちに生物分解 性（E260 非発現）と生物難分解性（E260 発現）の有 機物の存在比（TOC 比）を知门得る ${ }^{16)}$.

このようにして, 現在 BOD 成分として知られている $100 \sim 10 \mathrm{ppm}$ といった濃度の廃水中の有機物の第 1 主成 分に対して，その数\%のフミン質類が有機物の第 2 主成 分として繰返し水利用系では問題となる ${ }^{19)}$. この成分は また生物処理や分解を経た清澄な水中では，数 ppm 数+ppbのオーダーで存在する有機物の主成分であり, 臭や味, 発がん性物質などの極微量の ppb〜 ppt のオ一 ダーの有機物の挙動を論ずる際に常に基礎的な成分とし て共存していると考えなければならない．またこの成分 は自然水中できわめて安定であり，物質輸送・収支を論 ずる方程式中で保存量として扱い得る最も高濃度の有機 物と考えてよいであろう。

図一9は都市水代謝系の中で総合的にみて, 最も複雑 な構成をもっている下水中の溶解性成分 $(0.45 \mu \mathrm{m}$ フィ ルタ一通過成分）のゲルクロマトグラムである ${ }^{18)}$.この ようなクロマトグラムによる水の状態の表現は, 分子量 の大小別のグループ (グループ番号 $i$, または $K_{d}$ 值 $^{18)}$ ) と, そのグループの（TOC/E 260）比でなされる. た とえば，(1)林地よりの基底流出水: $i=2,4,6$ で TOC/E 260<50-30, (2)地表滞留時間の長い泥炭地水 : (1)のグループに $i=1$, TOC $/ \mathrm{E} 260<50-30$ のグルー プが加わる, (3)生下水：上述に $i=3$, TOC/E 260> 


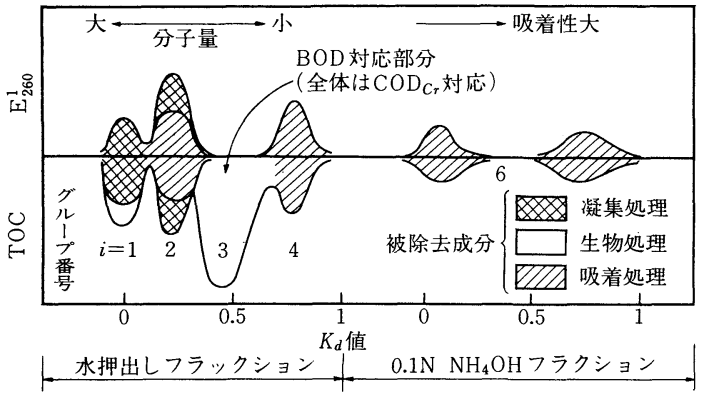

図一9 下水のゲルクロマトグラム

100-500 といったグループが加わり， $i=1$ の TOC/E 260 が 100 に近づく.

これらの水が,普遍的な水質変換プロセスである凝集, 生物分解，吸着を経ることによって図一9に示すように 変化する. 定量的な処理性の評価法については別報を参 照されたい ${ }^{16)}$. このようなゲルクロマトグラムによる水 質表現（水質マトリックス）によって，環境中に存在す る有機物の $95 \%$ （低濃度の水道原水のような場合）$99 \%$ （生下水などの高濃度の場合）の存在状態を, 除 去率 90 97\% 程度がせいぜいである現在の処理プロセ ス群と対応づけて実用的に十分な精度で挙動を評価し， 水システムを設計する場合の基礎とすることができる. しかしながら， $\mu \mathrm{g} / l$ レベル以下の濃度の微量塩素化有 機化合物やその他の発がん性や環境変異原性が問題とな る成分などを議論の対象としなければならぬ場合には， クロマトグラムに基づく制御の不確定部分の 1 5 \% と いったものを物質収支の誤差として扱うわけにはいかな いし，感度の十分でない TOC を基準とした評価法によ るわけにはいかず，別途な対応が必要になる.

\section{(微量有機污染物質)}

水の絽返し利用で最後に問題になる有機成分は農薬や その他の石油化学物質類などの微量成分である. 図一6 に示すように量的にはゲルクロマトグラフィーで表現で きるような成分が主体をなすが，成分数からいえば，ガ スクロマトグラフィー対応成分となるような低分子物質 がそのほとんどを占める．これらはまた，ゲルクロマト グラフィー（たとえば図一9）では吸着性の高いアンモ ニア水押出しのグループ 6 に出現する.

水中有機物の示す毒性といった点で考えると，(1)低分 子の有機物質の寄与がその主体となると考えてよい.さ らに，(2)きわめて低い濃度レベルで水と生体の間での分 配が生体の側に進むとすれば，その成分は親水性の高く ない（極性の低い成分や，疎水性をもつ分子などの）も のが対象となろう．農薬やさまざまな発がん性有機物質 の構造式を頭において考えると理解しやすいであろう. このような物質の同定・定量に用いられている最も一般
的な分離手段がガスクロマトグラフィーであり，低沸点 の有機物や溶媒によって水相から分離される, 疎水性で あまり沸点の高くない有機物群がその主対応成分であり 得る.これらの成分はゲルクロマトグラフィー（または 液体クロマトグラフィー) では分離評価しにくい成分で あって図一6に示すように情報の部分的オーバーラップ をもちつつも，ガスクロマトグラフィー等の導入による 次段の評価過程を構成し得る可能性をもつ.

したがって,これらの成分群はゲルクロマトグラ フィーに基づく評価では残余の成分，すなわち全体の， $2 \sim 3 \%$ 程度の $\mathrm{E} 260$ 発現成分を主体としたもので，そ の挙動が水道水等の生理的な用途の安全を論ずる主体と なる部分を含有していることになる，それらが，低分子 で疎水性をもつ成分が主体であろうことはゲルクロマト グラムの出現位置（アンモニア押出し区分）から明らか であり，活性炭吸着性をもつ成分グループがその成分に 対応すると考えてよいであろう．したがって，限外滤過 か凝集で高分子部分を除いて活性炭吸着を行うことが成 分を捕捉する第 1 の操作ということになろう.アメリカ 合衆国で十数年用いられてきた微量有機物示標の CCE などでは有用性が低い，これらの成分群においては，活 性炭吸着一溶媒等による抽出 $\rightarrow$ ガスクロマトグラ フィー分離 $\rightarrow$ マスペクトルによる同定・定量といっ た手順が最も正統的なものであろう. 抽出，ガスクロマ トグラフィーによる分離がなるべく単一（もしくは少な い）過程で総体をカバーしつつ進み, 必要な分離をどう とり得るかが主点となる．このような手法により，水道 原水となる清澄な水 (アメリカ合衆国ノースカロライナ) を亀井が測定した例を示すと図一10のようである．こ れらの成分のほとんどは農薬である.

このような成分を含んだ水を都市や地域の水代謝系で どのように扱っていけばよいかという点についての論議 はいまだ十分なされていない．飲料水に用いる分を上流 で分離し, 中流以下の河川を繰返し利用によって蓄積す る成分に対してそれほど問題にならない他の用途に残す といった上質水道系をもつ方法と, 現在の上水道に高度 処理を加え, 低質系の中水道・雑用水道をつくり水の量 を確保する繰返し利用を進めるといった $2 つ の$ 水資源の 使い分けのより詳細な議論がこのような成分の河川にお

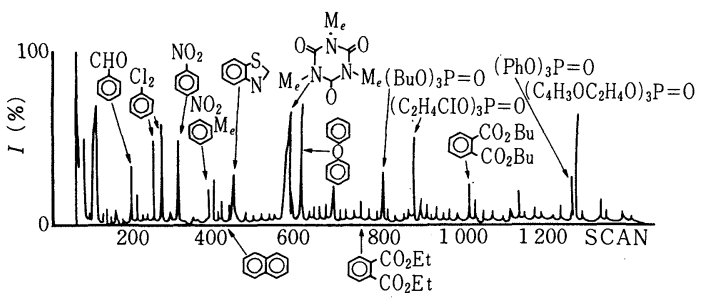

図一10 活性炭吸着アセトン抽出成分のガスクロマトグラム 
ける存在を考えたときに不可欠となる ${ }^{13)}$.

現在微量有機污染による人体影響について最も広く議 論されているのが，塩素消毒を受けた水や放流下水中に 生ずるトリハロメタン類 (THMs) やその他の塩素化合 物 $(\mathrm{TOX})$ 類で, 発癌性や環境変量原性を疑われてい る成分群である ${ }^{21)}$.

THMs や TOX は自然に存在する有機着色成分や下水 等の生物分解で生ずる代謝廃成分中のフミン質類を前駆 物質 (precursor) とし, 消毒のための塩素添加によっ て生ずる.これら前駆物質は, 前述のようにE 260 発現 性 TOC (フミン質類) として表記される成分であるか ら, THMs, TOX の生成ポテンシャル $(24 \mathrm{~h}$ 反応で残 留塩素 $1 \mathrm{mg} / l$ となるような条件での生成量）は図一11 に示すように E 260 值と直線関係を示して増加する.

WHO（国連保健機構）が推奨している THM as $\mathrm{CHCl}_{3}$ の濃度 $0.30 \mathrm{ppm}$ を制御目標值とすると, 水中に 存在し得る生物難分解性有機物（E260 発現成分）濃度 は $1 \mathrm{mg} / l$ 以下ということになり, 従来の一過型の害を なす有機成分 (BOD 発現型) の場合よりも制御すべき 濃度レベルを 1 桁低いところまで考えて水質管理をしな ければならない. THMs は多くの微量污染成分のうち で最も濃度の高い成分群であるとして問題になったわけ であるから, 他の微量有機成分の制御ではさらに低い濃 度をその対象としなければならないことになる。

生下水の BOD と TOC の比は $2 \sim 1.5$ 程度と考えら れるので生下水の TOC は平均的に $100 \mathrm{mg} / l$ 程度と考 えてよいであろう.そうすると下水の生物処理や河川の 自浄作用で下流に出現する好気性分解による生物代謝成 分中の $\mathrm{TOC}$ はその $3 \sim 5 \%$ 程度とみてよいから，フミ ン質類の TOC が $3 \sim 5 \mathrm{mg} / l$ 出現することになる. 前述 の図一3に示される荒川, 淀川や処理の進んだ下水の $\mathrm{BOD} / \mathrm{COD}$ 比が 1.2 程度の有機物の分解状況では, TOC/E260 の比は, 50〜70くらいと考えられるので, このような水を取水し浄水場で塩素処理をすればトリハ ロメタン類の生成可能濃度が $120 \sim 250 \mu \mathrm{g} / l$ といった值 に達する. わが国の水道水の制御目標值である THM $100 \mu \mathrm{g} / l$, 国連保健機構の目標値の THM $30 \mu \mathrm{g} / l$ を満 たすように下流の水質值を保つということになると，下

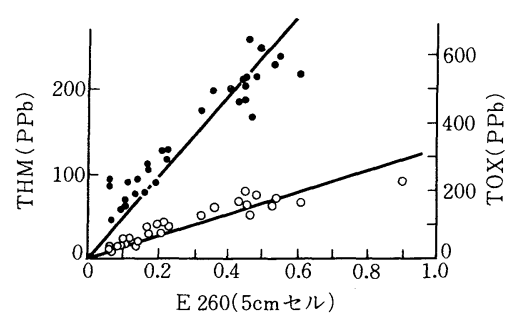

図-11E260 吸光度と THM，TOX生成能
水処理水が THM 生成能をもたぬ清浄水（実際はあり 得ない) で少なくとも 2 倍, できるならば 5 倍以上に希 釈されることが必要となる.さもなければ上水の高度処 理が不可欠となる. 淀川始め日本の多くの河川でここ数 年問題となっている事項である.

\section{（2）繰返し利用に伴う無機成分の問題}

水を繰返し用いることに由来するいま 1 つの問題は, 窒素 $(\mathrm{N})$ やリン $(\mathrm{P})$ などの無機成分の蓄積による河川・ 湖沼の富栄養化である.

わが国の河川中の平均的な無機塩濃度を半谷 ${ }^{22)}$ が模式 的に描いたものが図一12である．富栄養化によって藻 類などの微生物を湖沼や河川で大増殖させて問題となる $\mathrm{N}, \mathrm{P}$ は濃度的に無機第 2 主成分である. 第 2 主成分群 中の $\mathrm{F}, \mathrm{Fe}, \mathrm{Mn}$ などがすでに問題となり制御が行わ れていると同じように，N，Pについても問題が生じて

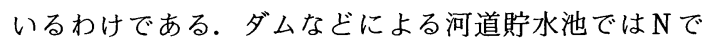
$0.5 \mathrm{mg} / l, \mathrm{P}$ で $0.05 \mathrm{mg} / l$ 程度以下の濃度であれば, 富 栄養化による藻類の増殖による害をあまり受けずにす む. 天然湖沼のような滞留時間の長いところではPが $0.01 \sim 0.02 \mathrm{mg} / l$ 以下であることが望まれる.

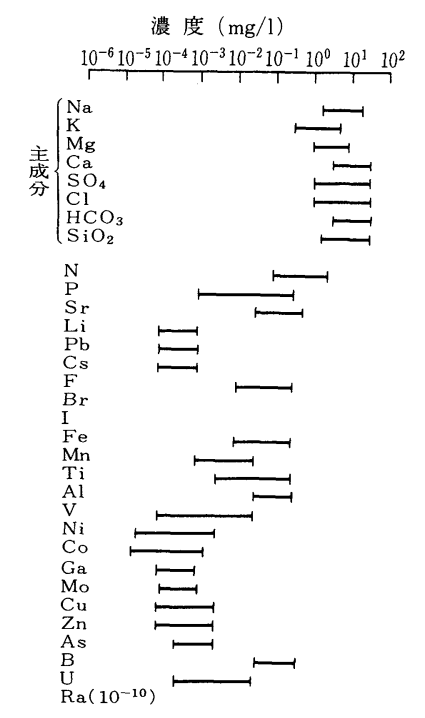

図一12 通常河川の成分濃度の概観 (半谷による)

表一1 N,P の排出量

\begin{tabular}{|c|c|c|c|}
\hline & \multicolumn{2}{|c|}{ 1人1日当たりに換算した排出量 } & \multirow{2}{*}{ 算 出 指 標 } \\
\hline & $\mathrm{N}$ & $\mathrm{P}$ & \\
\hline 都市廃水 & $12 \mathrm{~g} /$ 人/日 & $1.8 \mathrm{~g} /$ 人/日 & 流域下水計画指針（建設省） \\
\hline & $3.6 \mathrm{~g} /$ 人/日 & $0.036 \mathrm{~g} /$ 人/日 & $\begin{array}{l}\text { 総面積 (5500 000ha) } \\
\mathrm{N}: 30 \mathrm{~kg} / \mathrm{ha} / \mathrm{y} \quad \mathrm{P}: 0.3 \mathrm{~kg} / \mathrm{ha} / \mathrm{y} \\
\text { 人口 } 1.2 \text { 億人 }\end{array}$ \\
\hline 林 & $1.6 \mathrm{~g} /$ 人/日 & $0.16 \mathrm{~g} /$ 人/日 & $\begin{array}{l}\text { 総面積 }(25198000 \mathrm{ha}) \\
\mathrm{N}: 3 \mathrm{~kg} / \mathrm{ha} / \mathrm{y} \quad \mathrm{P}: 0.3 \mathrm{~kg} / \mathrm{ha} / \mathrm{y}\end{array}$ \\
\hline & $17.3 \mathrm{~g} /$ 人/日 & $4.1 \mathrm{~g} /$ 人/日 & 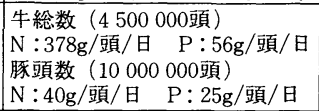 \\
\hline
\end{tabular}


それではこのような値がわが国の平均的な水代謝の大 きさとどのようにかかわってくるかを考えてみる. 国民 1 人当たりの $\mathrm{P}, \mathrm{N}$ の発生高をみると表一 1 のようにな り, 畜産, 都市活動からの発生部分が大きい. 工業, 水 産業は都市域の下流排出と考えてここでは計算に含まな いことにする.

水利用・流出の順を, (1)森林, (2)田畑, (3)畜産, (4)都 市の順に加えて行って, N, P がそれぞれ $0.2 \mathrm{mg} / l$, $0.02 \mathrm{mg} / l$ といった貯留域での富栄養化現象の発現の限 界にどのように近づいていくかを考えてみよう．上流が 森林のみの場合に $\mathrm{N}$ の流出は $3 \mathrm{~kg} / \mathrm{ha} \cdot \mathrm{Y}=3000 \mathrm{~g} /$ $10000 \mathrm{~m}^{2} \cdot 365$ 日 $=8.2 \times 10 \mathrm{~g} / \mathrm{m}^{2} \cdot$ 日 $=0.82 \mathrm{mg} / \mathrm{m}^{2}$. 日，賦存量を日量に換算すると $2.4 \mathrm{l} / \mathrm{m}^{2} /$ 日となるので, $\mathrm{N}$ の平均濃度は $0.82 \mathrm{mg} / \mathrm{m}^{2} /$ 日 $\div 2.4 \mathrm{l} / \mathrm{m}^{2} /$ 日 $=0.34$ $\mathrm{mg} / l$ となる. $\mathrm{P}$ の流出は $0.3 \mathrm{~kg} / \mathrm{ha} \cdot \mathrm{Y}$ と $\mathrm{N}$ の $1 / 10$ で あるから平均濃度は $0.034 \mathrm{mg} / l$ となる.

いずれの場合も流れ型のダム貯水池で富栄養化現象の 起こる限界のレベル $\mathrm{N}=0.5 \mathrm{mg} / l, \mathrm{P}=0.05 \mathrm{mg} / l$ と自 然湖沼でいわれている $\mathrm{N}=0.1 \sim 0.2 \mathrm{mg} / l, \mathrm{P}=0.01$ $0.02 \mathrm{mg} / \mathrm{l}$ の中間的な值となり, 普通の森林からの流出 でも問題が生じ得るレベルにあることを示している.

田畑加の流出が加わると, 窒素では流過分に対して は 10 倍近くの濃度が, リンに対しては 2 倍くらいの濃 度となる. 田畑の面積比が森林の $1 / 5$ 程度であるから, $\mathrm{N}$ で 2 3 倍, $\mathrm{P}$ で 1.2 1. 3 倍といった濃度増加が田 烟を流下することによって加えられよう. したがって， $\mathrm{N}$ で $1 \mathrm{ppm}$ 以上， $\mathrm{P}$ で 0.4 0.45 ppm くらいの濃度が 普通となって流れ型の貯水池でも富栄養化は避けられな いことになる。

畜産廃水も放牧してある牛の場合 $10 \%$ 以下くらいの 流出をみなければならないとされている。一方，豚や二 ワトリは近年污泥処理が十分に行われほとんど污濁負荷 の流出がないとし得る状況も出現している.

中流部における $\mathrm{N}, \mathrm{P}$ の流入と挙動については平均 的な論議でも富栄養化が問題となるので, 貯留を伴う場 合にはわが国では富栄養化は普通に出現する問題と考え てよいであろう．BOD 型の污濁に次いで自然域での残 された大きな問題として現われる. 問題の扱いの段階と しては, Streeter-Phelps の体系と次節で述べる高度水 質管理系の中間に位置するものであろう．この場合，P は保存量として扱い得るが $\mathrm{N}$ はそうはいかず，生産有機 物量を含めての議論を難しくする.

\section{5. 高度水管理系での成分の流れと収支}

繰返し利用を必要とするような高度水管理系で扱われ る成分群の特徴は, (1)対象とすべき成分群が多様である, (2)低濃度の成分群まで扱わねばならない，(3)成分群の多
くが保存量として扱えるような安定な成分かまたはきわ めて変化速度の遅い成分群である，といったことであろ う.

したがって，このような多くの成分群を，水・空気・ 土壌といった 3 相系のしかるべきところにしかるべき形 態で分配し，環境の価值を保ち続け，状態を正確に把握 し続けるためには, 分散型の輸送と広い空間で多様な生 態系により質変換と相間の分配を行う自然の作用に多く を依存するわけにはいかない．式（1）の左辺第 2 項を なるべく小さくすることが制御の第一歩となる，そのた めには，輸送径路を平均流によるような単純明確なもの とし，他系との成分の交換や変化がなるべく集中して生 ずるような系の構造をとる必要がある．すなわち，水処 理による成分群の諸相・諸空間への明確な分配を重視す る系の採用である.

図一4に示すように，水の大循環経路における水質の 制御は, 水質成分群が水サイクルと共役になる点（利水 点）之共役を解除する点 (水処理) の 2 か所で行われる. 水処理点で成分の共役解除に用い得る実用的なプロセス とその対応成分の範囲は限られているから，エネル ギー・費用の大きな非実用的プロセスによらねばならぬ ような成分群は水サイクルと共役させない（水系に接触 させない）ことが原則となる.

共役を解除すべき水処理点で実用し得る分離・分配の プロセスは限られた数のものであり，図一13に示すよ うに分画した成分群のマトリックスと対応する．図にみ られるように，分画されて水質変換の観点から性格付け られた水質成分群について, 実用されている諸プロセス はあまり大きな重複をみせずに対応する。このことは， 式（1）に示した成分 $i$ の動力学・分離項をすべての成 分群に必ずしも絡み合わせなくてもよいことを意味し， プロセスを多段階に直列に配して，各段の独立性をかな り高くとって収支を明確にした制御を行う可能性を示唆 する.このようなことを, 自然環境で諸分離・分配プロ セスが混在しているところで行おうとすると, 扱い難い 混乱を環境系に導入することになる。

環境に都市や地域の水代謝をどのように収めるべきか

\begin{tabular}{|c|c|c|c|c|c|}
\hline & \multicolumn{2}{|c|}{ 有 機 物 } & \multicolumn{3}{|c|}{ 無 機 物 } \\
\hline & $\begin{array}{l}\text { 生物分解性 } \\
\text { BOD, } \\
\text { E260非発現 }\end{array}$ & $\begin{array}{l}\text { 生物分解性 } \\
\mathrm{COD} \mathrm{D}_{\mathrm{r}}-\mathrm{BOD}, \\
\mathrm{E} 260 \text { 発現 }\end{array}$ & $\left.\begin{array}{c}\text { 有機錯体 } \\
\text { 大多数は } \\
(\text { フミン質と }\end{array}\right)$ & 易凝析性 & 難 変 性 \\
\hline $\begin{array}{l}\text { 懸濁性 } \\
\text { 成分 }\end{array}$ & 細 菌 & $\begin{array}{l}\text { 有機性土/ } \\
\text { 《生物処理》 }\end{array}$ & 《化学凝集処 & 理》 & シルト \\
\hline $\begin{array}{l}\text { コロイド } \\
\text { 成分 }\end{array}$ & $\begin{array}{c}\text { ウイルス } \\
\text { 蛋白類 } \\
\text { など }\end{array}$ & フン & & 《膜分離》 & 一粘土一 \\
\hline $\begin{array}{l}\text { 溶解性 } \\
\text { 成分 }\end{array}$ & 味 & $\begin{array}{r}\text { 臭物質《活性 } \\
\text { フ } \\
\text { DDT,BHCなど }\end{array}$ & 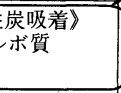 & $\begin{array}{c}\text { 〈碀析〉 } \\
\mathrm{Fe}^{2+}, \mathrm{Mn}^{2+} \\
\mathrm{Cd}^{2+} \text { など }\end{array}$ & $\begin{array}{l}\langle\text { 〈オン交換 } \\
\mathrm{Na}^{+}, \mathrm{Cl}^{-} \\
\mathrm{NO}_{3}^{-} \text {など }\end{array}$ \\
\hline
\end{tabular}

図一13成分群と処理プロセスの対応 
という議論は，紙幅の制限もあって別な機会に譲らざる を得ないが，環境制御といった点に論を絞るならば， Streeter-Phelps 型の解析や富栄養化のアセスメントの ための諸解析を超えたところに, 高度水管理系での成分 輸送と分離・分配の研究の核心が向かわねばならぬよう に思われる.

\section{参 考 文 献}

1) Phelps, E. B. : Stream Sanitation, John Wiley and Sons, Inc. Third Edition (最終版絶版), 1953.

2) Himmelblau, D. M. and Bischoff, K. B. (井本立也ほか 訳) : プロセス解析計算法, 培風館, 1971.

3）岩井重久・住友 恒・松岡 譲: 水質デー夕の統計的解 析, 森北出版, 1980 .

4) 丹保憲仁 : 水代謝系の変遷と安全, 都市問題研究, 33 巻 8 号, pp. 15 27, 昭 56 年 8 月.

5) 合田 健編：水質工学 (応用編), 第 10 章, 丸善, 1971.

6) Mikio HINO : Ecohydrodynamics, Advances in hydroscience Vol. 12, pp. 143 193, Academic press, 1981.

7）たとえば,日本河川協会編：建設省河川砂防技術基準(案) 調査・計画編，第 14 章, 山海堂, 1977.

8) APHS, AWWA, WPCF : Standard Method for the examination of water and wastewater, 16th edition, 1985.

9）環境庁，水質污濁に係る環境基準，(昭 46.12).

10) Eckenfelder, W.W. and O'connor, D. J. : Biological Waste Treatment, Pergamon press, 1961.

11）金子光美・藤田賢二：水処理(単位操作と産業用・廃水), 新体系土水工学 90 , 第 3 章, 技報堂, 1982 .

12）丹保憲仁：都市・地域水代謝システムの構造と容量, 水 道協会雑誌, 497 号, pp. 16 34, 昭 51.2.
13）丹保憲仁：新上質水道論（高密度地域における飲用確保 と確率的渴水災害からの離脱のために), 北海道大学工学 部研究報告, 113 号, pp. 1 11, 昭 58.2.

14) Sontheimer, H. : The Rhine and domestic water supply, Paper of the plenty session on the river Rhine, International water supply association 11th congress at Amsterdam, 1976.

15) Tambo, N. and Kamei, T. : Treatability evaluation of general organic matter. Matrix conception and its application for a regional water and waste water system, Water research, Vol. 12, pp. 931 950, 1979.

16）丹保憲仁・亀井 翼：処理性評価のための水質変換マ卜 リックス, [I] [III], 水道協会雑誌, 530 号, pp. 8 18, 昭 53.11, 531 号, pp. $15 \sim 24$, 昭 53.12, 532 号, pp. 37 $\sim 44$, 昭 54.1 .

17）丹保憲仁. 龟井 翼: 下廃水処理と飲料水の安全, PPM, pp. 2 11, 1985-5.

18) Tambo, N. and Kamei, T. : New water quality indices of organics for the evaluation of treatment process and self-purification, Proc. 5th Asian pacific region water supply conference, Seoul 1985.

19）丹保憲仁・亀井 翼・高橋良宏：好気性生物化学プロセ スからの代謝廃成分の挙動と性質（1）, 下水道協会誌, 18 巻, 210 号, pp. 1 10, 1981-11.

20）亀井 翼・丹保憲仁：好気性生物化学プロセスからの代 謝廃成分の挙動と性質 (IV)，19 巻，213 巻，pp.1〜10, 1982-2.

21）丹保憲仁編著：水道とトリハロメタン，技報堂，1983.

22）半谷高久：水質調查法 (旧版), 丸善, 昭 35 .

(1985.10.2 • 受付) 